\section{Kidney \\ Blood Pressure Research}

\title{
Renal Involvement in AA Amyloidosis: Clinical Outcomes and Survival
}

\author{
Murvet Yilmaz ${ }^{\mathrm{a}} \quad$ Abdulkadir Unsal $^{\mathrm{b}} \quad$ Mehmet Sokmen $^{\mathrm{c}}$ \\ Ozlem Harmankaya Kaptanogullaria ${ }^{\text {Canan Alkim }}{ }^{d}$ Fevziye Kabukcuoglue \\ Aysim Ozagarie Emire Bor ${ }^{f}$
}

aNephrology Department, Bakirkoy Dr. Sadi Konuk Training and Research Hospital, Istanbul, Turkey; ${ }^{b}$ Nephrology Department, Sisli Etfal Training and Research Hospital, Istanbul, Turkey; ' Gastroenterology Department, Umraniye Training and Research Hospital, Istanbul, Turkey; ${ }^{\mathrm{d} G a s t r o e n t e r o l o g y ~ D e p a r t m e n t, ~}$

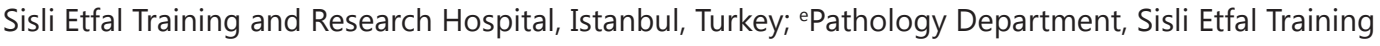

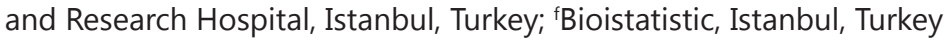

\section{Key Words}

AA amyloidosis $•$ Chronic kidney disease $•$ Proteinuria $\bullet$ Survival

\begin{abstract}
Background: The natural history of AA amyloidosis is typically progressive, leading to multiple organ failure and death. We analyzed the etiology as well as clinical and laboratory features of patients with biopsy-proven AA amyloidosis and evaluated the ultimate outcome. Methods: Seventy-three patients (24 female; mean age $41.85 \pm 15.89$ years) were analyzed retrospectively. Demographic, clinical and laboratory features were studied and the outcome was assessed. Results: Familial Mediterranean Fever and tuberculosis were the most frequent causes of amyloidosis. Mean serum creatinine and proteinuria at diagnosis were $4.65 \pm 4.89$ $\mathrm{mg} / \mathrm{dl}$ and $8.04 \pm 6.09 \mathrm{~g} /$ day, respectively; and stage I, II, III, IV and V renal disease were present in $19.2 \%, 13.7 \%, 16.4 \%, 11 \%$, and $39.7 \%$ of the patients, respectively. ESRD developed in 16 patients during the follow-up period. All of the ESRD patients started a dialysis programme. Thirty patients (41\%) died during the follow-up period; median patient survival was $35.9 \pm 6.12$ months. Old age, tuberculosis etiology, advanced renal disease and low serum albumin levels were associated with a worse prognosis. Serum albumin was a predictor of mortality in logistic regression analysis. Conclusion: The ultimate outcome of the patients with AA amyloidosis is poor, possibly due to the late referral to the nephrology clinics. Early referral may be helpful to improve prognosis.
\end{abstract}




\section{Kidney Blood Pressure Research}

\section{Introduction}

Amyloidosis is a group of rare systemic diseases in which a specific protein, amyloid, is deposited as aggregated interstitial fibrils that can compromise organ function and lead to death [1]. Amyloid deposition may be found in many organs; however, most of the time renal involvement dominates the clinical picture [2]. Patients typically present with nephrotic syndrome and progressive renal failure, leading to end stage renal disease (ESRD) [3].

The natural history of AA amyloidosis is typically progressive, leading to organ failure and death, when the underlying inflammatory diseases remain active [4]. Therapeutic possibilities, which could affect the development of AA amyloidosis, are rather limited. However, long-term survival depends, particularly, on the achievement of stable, complete control of the underlying inflammatory process [1].

Although renal involvement is quite common in systemic amyloidosis, data on survival and renal outcome of patients with this problem is scarce. Complications of ESRD are the main cause of death, and median survival after diagnosis varies between four and ten years $[2,5]$. Joss et al. [2] demonstrated that albuminuria and impaired renal function are poor prognostic factors in patients with AA amyloidosis.

Amyloid nephropathy is common in Turkey due to the high incidence of Familial Mediterranean Fever (FMF) and infections, especially tuberculosis. In this paper, we retrospectively analyzed etiology, clinical and laboratory features and also the ultimate outcome of the patients with AA amyloidosis.

\section{Materials and Methods}

The files of 80 patients [52 males, 28 females; mean age $42.33 \pm 15.45$ (range 17-77) years] with biopsy-proven systemic AA amyloidosis were retrospectively reviewed. All patients with at least one clinical control after diagnosis were included in the study. Seven patients were excluded because they were lost to follow-up.

Biopsy indications for the patients during the initial diagnosis were proteinuria, nephrotic syndrome, and/or renal dysfunction. All patients had evidence of amyloid deposits in renal biopsy and/or in alternate site biopsies such as gastrointestinal tract (GIT) (esophagus, antrum, duodenum and rectum) or gingiva.

Amyloidosis was histologically proven in all patients by light microscopy using hematoxylin-eosin (HE) and crystal violet staining. All of the specimens were evaluated by the same pathologist. Amyloid-A component antibody was investigated through immunohistochemical study.

The following clinical and laboratory variables were evaluated: age, gender, underlying disease; serum urea, creatinine, albumin, cholesterol, triglyceride levels; and also quantity of daily proteinuria. The creatinine clearance was calculated by means of the MDRD-4 formula. Renal disease was classified according to K/DOQI-NKF guideline. Date of onset and type of dialysis and causes of death were recorded, if identified.

Follow-up period included the duration from diagnosis to the last clinical control or to death of the patients. The primary end-points were the start of renal replacement therapy and death. Renal survival was calculated using the time interval between diagnosis and the beginning of dialysis (kidney death).

In general, treatment aimed to suppress the activity of the underlying disease. Also, all patients underwent supportive therapy for both nephrotic syndrome and/or renal insufficiency including, when required, renal-replacement therapy.

The cause of death was systematically investigated and registered in order to differentiate the conditions directly related to progression of amyloidosis (cachexia, malnutrition, infection) or related to the complications of renal disease such as hyperkalemia and hypervolemia. Deaths were recorded as 'unknown' whenever the exact cause was not reported.

Statistics

NCSS (Number Cruncher Statistical System) 2007 \& PASS (Power Analysis and Sample Size) 2008 Statistical Software (Utah, USA) programs were used for the statistical analysis. During the comparisons of descriptive statistical methods (mean, standard deviation, median, frequency, rate), Student t test was 


\section{Kidney \\ Blood Pressure Research}

Kidney Blood Press Res 2013;37:33-42

DOI: 10.1159/000343398

Published online: March 12, 2013

C 2013 S. Karger AG, Base

Yilmaz/Unsal/Sokmen et al.: Renal Involvement in AA Amyloidosis

Table 1. Etiology of amyloidosis, demographic features of the patients and laboratory findings at the time of diagnosis

\begin{tabular}{|c|c|c|}
\hline \multirow{2}{*}{ Age (years) } & & Patients $(n=73)$ \\
\hline & & $41.85 \pm 15.89$ \\
\hline Gender (female & & $24 / 49$ \\
\hline \multirow{6}{*}{ Etiology } & FMF & 19 \\
\hline & Tuberculosis & 16 \\
\hline & COPD & 8 \\
\hline & Rheumatologic diseases & 5 \\
\hline & Others & 4 \\
\hline & Unknown etiology & 21 \\
\hline \multirow{5}{*}{ Serum } & Urea (mg/dl) & $96.80 \pm 84.91$ \\
\hline & Creatinine (mg/dl) & $4.65 \pm 4.89$ \\
\hline & $\operatorname{Albumin}(\mathrm{g} / \mathrm{dl})$ & $2.45 \pm 1.01$ \\
\hline & Cholesterol (mg/dl) & $251.77 \pm 100.59$ \\
\hline & Triglyceride (mg/dl) & $215.92 \pm 132.03$ \\
\hline \multicolumn{2}{|c|}{ Proteinuria (g/day) } & $8.04 \pm 6.09$ \\
\hline \multirow{5}{*}{ Renal disease } & Stage 1 & $14(19.2 \%)$ \\
\hline & Stage 2 & $10(13.7 \%)$ \\
\hline & Stage 3 & $12(16.4 \%)$ \\
\hline & Stage 4 & $8(11.0 \%)$ \\
\hline & Stage 5 & $29(39.7 \%)$ \\
\hline Died/Alive (n) & & $30 / 43$ \\
\hline \multirow{2}{*}{ Dialysis (n) } & at diagnosis & 29 \\
\hline & during the follow-up period & 16 \\
\hline
\end{tabular}

Table 2. Demographic features of the patients with FMF and tuberculosis as the etiology of amyloidosis and laboratory findings at the time of diagnosis

FMF: Familial Mediterranean Fever, COPD: chronic obstructive pulmonary disease

$\nabla$

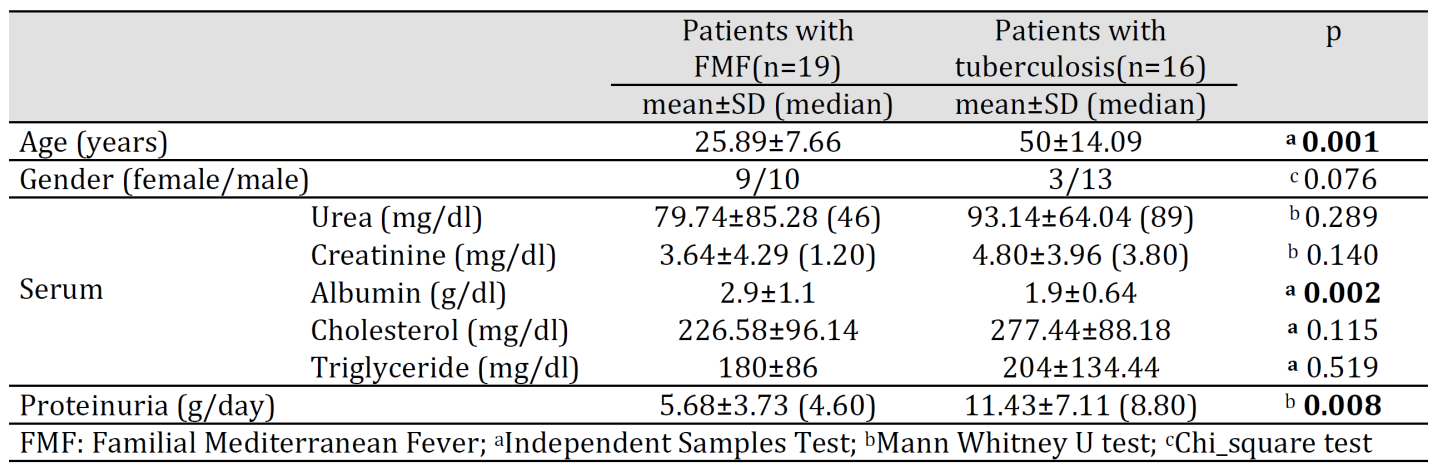

used for the intergroup comparisons of parameters with normal distribution and Mann Whitney U test was used for the intergroup comparisons of parameters without normal distribution. Yates Correction Chi square test and Fisher's exact test were used for comparison of qualitative data. Multivariate analyses were performed by Enter Logistic Regression analysis. Survival was estimated by means of Kaplan-Meier and Log Rank (Mantel-Cox) test. P value $<0.05$ was considered as significant.

\section{Results}

Of the 73 patients, 49 were males and 24 females. Mean age was $41.85 \pm 15.89$ (range 17 77 ) years. The mean follow-up period was $21.10 \pm 20.76$ (0.5 to 101.1) months. Demographic features of the patients, etiology and laboratory findings at diagnosis are shown in table 1. FMF and tuberculosis were the most frequent causes of amyloidosis, being followed by chronic obstructive pulmonary disease and chronic rheumatologic diseases. The patients with tuberculosis as the etiology of amyloidosis were significantly older, had lower serum albumin and higher daily proteinuria than the patients with FMF at the time of diagnosis (table 2). 


\section{Kidney Blood Pressure Research}

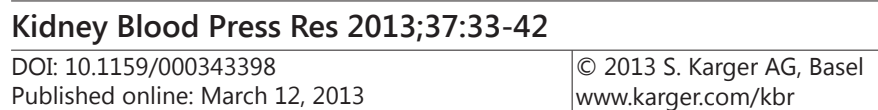

Yilmaz/Unsal/Sokmen et al.: Renal Involvement in AA Amyloidosis

The histological diagnosis of amyloidosis had been made by renal biopsies in $57.53 \%$ patients. Gastrointestinal tract (GIT) biopsies had also been performed when renal biopsy was contraindicated. Amyloidosis was found to be present in $98.36 \%$ of the duodenal biopsies, $85.71 \%$ of the antral biopsies, $83.93 \%$ of the rectal biopsies, $54.29 \%$ of the esophageal biopsies and $27.27 \%$ of the gingival biopsies. In renal biopsy specimens, amyloid deposits were mainly located at the glomerulus showing a mesangial nodular pattern. In most of them, amyloid deposition was found at the blood vessel walls as well. In the histological examination of the gastrointestinal biopsy specimens, amyloid deposits were located in the vascular walls and stroma of the lamina propria, mucosa, and submucosa. By immunohistochemical study, all biopsy samples were positive for amyloid A component antibody.

41 patients were admitted with a clinical picture of nephrotic syndrome. Mean serum creatinine and urea levels at diagnosis were $4.65 \pm 4.89$ (range: $0.4-19.6$ ) $\mathrm{mg} / \mathrm{dl}$ and $96.80 \pm 84.91$ (range: $3-345$ ) mg/dl, respectively. At this time point, stage I, II, III, IV and V renal disease were present in $19.2 \%, 13.7 \%, 16.4 \%, 11 \%$, and $39.7 \%$ of the patients, respectively. At the time of diagnosis, 5 patients were anuric. In the remaining patients, mean proteinuria was $8.04 \pm 6.09$ (range $0.4-25$ ) g/day; 19 patients $(26.03 \%$ ) had urinary protein excretion more than 10 g per day; in 5 patients (6.85\%) this amount exceeded even 20 g per day. Mean serum albumin level was $2.45 \pm 1.01$ (range: $0.7-5.2$ ) g/dl; serum albumin concentration was less than $3.5 \mathrm{~g} / \mathrm{dl}$ in $61(83.56 \%)$ patients.

\section{Survival}

Thirty of the 73 patients died during the follow-up period. Patient survival was mean $55.52 \pm 6.12$ (median: 35.90 ) months. 19 of the 30 patients died during the first 12 months, 10 patients died between $12-24$ months and 1 patient died at the 36th month. One and two year survival rates were $53 \%$ and $50.3 \%$, respectively.

The nonsurvivors were significantly older, more frequently suffered from tuberculosis, and had more advanced renal disease and lower serum albumin. Patients with FMF as the etiology of amyloidosis were characterized by a more favourable outcome. There were no differences considering gender, urea, cholesterol, triglyceride levels or proteinuria at diagnosis between the survivors and nonsurvivors (table 3).

A multivariate logistic regression analysis, (which included the variables of age, presence of tuberculosis, advanced stage chronic kidney disease defined as stage IV and V, serum urea, creatinine and albumin levels), indicated hypoalbuminemia as a predictor of death (table 4).

Mean patient survival in stages I, II, III, IV and V were 52.49 $\pm 8.41,84.34 \pm 14.99$, $58.70 \pm 13.44,8.59 \pm 1.82$, and $25.27 \pm 3.51$ months, respectively. Overall one and two-year patient survival rates in various strata of kidney function are shown in table 5 and figure 1.

One-year patient survival rates, in patients with serum albumin $\geq 3.5 \mathrm{~g} / \mathrm{dl}$ and $<3.5 \mathrm{~g} / \mathrm{dl}$ were $91.7 \pm 8.0 \%$ and $67.6 \pm 6.3 \%$, respectively (table 5; figure 2).

Survival rate was not different with regard to serum cholesterol $(\geq 200 \mathrm{mg} / \mathrm{dl}$ versus $<200 \mathrm{mg} / \mathrm{dl}$ ), triglyceride $(\geq 200 \mathrm{mg} / \mathrm{dl}$ versus $<200 \mathrm{mg} / \mathrm{dl})$ and proteinuria $(\geq 3.5 \mathrm{~g} /$ day versus $<3.5 \mathrm{~g} /$ day) levels (table 5 ).

\section{Dialysis}

In $29(39.7 \%)$ of the 73 patients, ESRD was present at diagnosis. During the follow-up period, ESRD developed in 16 of the remaining patients as well. All of the ESRD patients started a dialysis programme. 41 patients were treated by hemodialysis (HD), while 4 patients started peritoneal dialysis (PD). During the follow-up period, 8 HD patients were switched from HD to PD, while 1 PD patient was switched from PD to HD. The median followup period on dialysis was $8.47 \pm 12.50$ months; this duration was $6.12 \pm 12.07$ months in PD and $3.80 \pm 11.97$ in HD.

Median survival on dialysis was 20.13 months. Survival in patients who needed dialysis treatment and in patients who were not on dialysis was $33.14 \pm 4.64$ and $76.85 \pm 8.66$ months, respectively. In patients receiving dialysis, one and two-year patient survival was $64.4 \pm 7.4 \%$ 


\section{Kidney Blood Pressure Research}

\section{Kidney Blood Press Res 2013;37:33-42}

DOI: $10.1159 / 000343398$

Published online: March 12, 2013

(C) 2013 S. Karger AG, Basel

www.karger.com/kbr

Table 3. Comparison of various parameters at the time diagnosis between patients who died versus survived during the follow-up period

\begin{tabular}{|c|c|c|c|c|}
\hline \multirow{2}{*}{ Age (years) } & & Died $(n=30)$ & Alive $(n=43)$ & $\mathrm{p}$ \\
\hline & & $47.00 \pm 17.00$ & $38.26 \pm 14.18$ & 0.020 \\
\hline \multicolumn{2}{|l|}{ Gender (female/male) } & $8 / 22$ & $16 / 27$ & 0.490 \\
\hline \multirow{6}{*}{ Underlying disease } & FMF & $2(6.7 \%)$ & $17(39.5 \%)$ & 0.004 \\
\hline & Tuberculosis & $11(36.7 \%)$ & $5(11.6 \%)$ & 0.024 \\
\hline & COPD & $5(16.7 \%)$ & $3(7 \%)$ & 0.260 \\
\hline & Rheumatologic diseases & $2(6.7 \%)$ & $3(7 \%)$ & 1.000 \\
\hline & Others & $2(6.7 \%)$ & $2(4.7 \%)$ & 1.000 \\
\hline & Unknown etiology & $8(26.7 \%)$ & $13(30.2 \%)$ & 0.945 \\
\hline \multirow{5}{*}{ Renal failure } & Stage 1 & $4(13.3 \%)$ & $10(23.3 \%)$ & 0.449 \\
\hline & Stage 2 & $1(3.3 \%)$ & $9(20.9 \%)$ & 0.040 \\
\hline & Stage 3 & $4(13.3 \%)$ & $8(18.6 \%)$ & 0.750 \\
\hline & Stage 4 & $5(16.7 \%)$ & $3(7 \%)$ & 0.260 \\
\hline & Stage 5 & $16(53.3 \%)$ & $13(30.2 \%)$ & 0.047 \\
\hline \multicolumn{2}{|l|}{ MDRD (Median) } & $32.90 \pm 42.59$ & $58.70 \pm 56.49$ & 0.032 \\
\hline \multirow{5}{*}{ Serum } & Urea (mg/dl) & $106.03 \pm 67.69$ & $90.35 \pm 95.36$ & 0.076 \\
\hline & Creatinine $(\mathrm{mg} / \mathrm{dl})$ & $5.48 \pm 4.61$ & $4.06 \pm 5.05$ & 0.034 \\
\hline & Albumin $(\mathrm{g} / \mathrm{dl})$ & $1.83 \pm 0.71$ & $2.89 \pm 0.96$ & 0.001 \\
\hline & Cholesterol (mg/dl) & $254.93 \pm 96.71$ & $249.56 \pm 104.29$ & 0.749 \\
\hline & Triglyceride $(\mathrm{mg} / \mathrm{dl})$ & $218.97 \pm 122.17$ & $213.79 \pm 139.88$ & 0.695 \\
\hline \multicolumn{2}{|l|}{ Proteinuria (g/day) } & $8.67 \pm 5.26$ & $7.67 \pm 6.56$ & 0.156 \\
\hline
\end{tabular}

Table 4. Multivariate logistic regression analysis of the factors that may affect mortality

\begin{tabular}{lcccc}
\hline & \multirow{2}{*}{$\mathrm{P}$} & \multirow{2}{*}{ ODDS } & \multicolumn{2}{c}{ \%95 CI } \\
\cline { 4 - 5 } & & & Lower & Upper \\
\hline Age $>$ 45 years & 0.400 & 1.677 & 0.503 & 5.590 \\
Tuberculosis as the underlying etiology & 0.141 & 2.679 & 0.722 & 9.943 \\
Renal disease (advance stage) & 0.156 & 3.097 & 0.650 & 14.757 \\
Serum albumin $<3,5 \mathrm{~g} / \mathrm{dl}$ & $\mathbf{0 . 0 4 5}$ & 8.911 & 1.005 & 83.536 \\
Serum creatinine & 0.715 & 1.041 & 0.840 & 1.290 \\
Serum urea & 0.618 & 0.997 & 0.984 & 1.010 \\
\hline
\end{tabular}

Table 5. Survival analysis according to stage of renal disease, serum albumin, cholesterol, triglyceride and proteinuria levels and need of dialysis support

\begin{tabular}{|c|c|c|c|c|c|c|c|c|c|c|}
\hline & & $\mathrm{n}$ & Ex & Alive & $\begin{array}{l}\text { Survival } \\
\text { rate }\end{array}$ & $\begin{array}{c}\text { One-year } \\
\text { patient } \\
\text { survival rate }\end{array}$ & $\begin{array}{c}\text { Two-year } \\
\text { patient } \\
\text { survival rate }\end{array}$ & $\begin{array}{c}\text { Mean } \\
\text { patients } \\
\text { survival }\end{array}$ & $\begin{array}{c}95 \% \\
\text { Confidence } \\
\text { Interval } \\
\text { Lower-Upper }\end{array}$ & $\mathrm{p}$ \\
\hline \multirow{5}{*}{$\begin{array}{l}\text { Renal } \\
\text { disease }\end{array}$} & Stage 1 & 14 & 4 & 10 & $71.4 \%$ & $78.6 \pm 11.0 \%$ & $69.8 \pm 12.8 \%$ & $52.49 \pm 8.41$ & $36.00-68.98$ & \multirow{5}{*}{0.031} \\
\hline & Stage 2 & 10 & 1 & 9 & $90.0 \%$ & - & $80.0 \pm 17.9 \%$ & $84.34 \pm 14.99$ & $54.95-113.72$ & \\
\hline & Stage 3 & 12 & 4 & 8 & $66.7 \%$ & $79.5 \pm 13.1 \%$ & $56.8 \pm 16.5 \%$ & $58.70 \pm 13.44$ & $32.34-85.06$ & \\
\hline & Stage 4 & 8 & 5 & 3 & $37.5 \%$ & $42.9 \pm 18.7 \%$ & $21.4 \pm 17.8 \%$ & $8.59 \pm 1.82$ & $5.03-12.16$ & \\
\hline & Stage 5 & 29 & 16 & 13 & $44.8 \%$ & $67.3 \pm 9.0 \%$ & $36.3 \pm 10.5 \%$ & $25.27 \pm 3.51$ & $18.38-32.16$ & \\
\hline \multirow[t]{2}{*}{ Albumin } & $\geq 3.5 \mathrm{~g} / \mathrm{dl}$ & 12 & 1 & 11 & $91.7 \%$ & $91.7 \pm 8.0 \%$ & & $92.84 \pm 7.90$ & $77.35-108.33$ & \multirow[t]{2}{*}{0.027} \\
\hline & $<3.5 \mathrm{~g} / \mathrm{dl}$ & 61 & 29 & 32 & $52.5 \%$ & $67.6 \pm 6.3 \%$ & $45.8 \pm 7.1 \%$ & $37.12 \pm 4.45$ & $28.38-45.85$ & \\
\hline \multirow[t]{2}{*}{ Cholesterol } & $\geq 200 \mathrm{mg} / \mathrm{dl}$ & 47 & 22 & 25 & $53.2 \%$ & $67.7 \pm 7.2 \%$ & $45.9 \pm 8.4 \%$ & $36.07 \pm 5.27$ & $25.74-51.08$ & \multirow[t]{2}{*}{0.083} \\
\hline & $<200 \mathrm{mg} / \mathrm{dl}$ & 26 & 8 & 18 & $69.2 \%$ & $79.6 \pm 8.2 \%$ & $63.9 \pm 10.5 \%$ & $69.13 \pm 9.21$ & $51.08-87.17$ & \\
\hline \multirow[t]{2}{*}{ Triglyceride } & $\geq 200 \mathrm{mg} / \mathrm{dl}$ & 31 & 13 & 18 & $58.1 \%$ & $78.6 \pm 7.8 \%$ & $50.2 \pm 10.7 \%$ & $38.53 \pm 6.52$ & $25.75-51.31$ & \multirow[t]{2}{*}{0.726} \\
\hline & $<200 \mathrm{mg} / \mathrm{dl}$ & 42 & 17 & 25 & $59.5 \%$ & $72.8 \pm 7.0 \%$ & $53.7 \pm 8.5 \%$ & $58.98 \pm 7.65$ & 43.99-73.98 & \\
\hline \multirow[t]{2}{*}{ Proteinuria } & $\geq 3.5 \mathrm{~g} /$ day & 57 & 23 & 34 & $59.6 \%$ & $73.3 \pm 6.2 \%$ & $55.0 \pm 7.3 \%$ & $42.49 \pm 4.64$ & $33.39-51.58$ & \multirow[t]{2}{*}{0.291} \\
\hline & $<3.5 \mathrm{~g} /$ day & 11 & 2 & 9 & $81.8 \%$ & $81.8 \pm 11.6 \%$ & - & $83.81 \pm 11.06$ & $62.12-105.49$ & \\
\hline \multirow[t]{2}{*}{ Dialysis } & $\begin{array}{l}\text { Entered } \\
\text { dialysis }\end{array}$ & 45 & 24 & 21 & $46.7 \%$ & $64.4 \pm 7.4 \%$ & $56.1 \pm 7.9 \%$ & $33.14 \pm 4.64$ & $24.04-42.22$ & \multirow[t]{2}{*}{0.029} \\
\hline & $\begin{array}{l}\text { Without } \\
\text { dialysis }\end{array}$ & 28 & 6 & 22 & $78.6 \%$ & $84.4 \pm 7.2 \%$ & $73.9 \pm 9.4 \%$ & $76.85 \pm 8.66$ & 59.88-93.83 & \\
\hline
\end{tabular}




\section{Kidney Blood Pressure Research}

Fig. 1. Patients survival according to stage classification of renal disease.

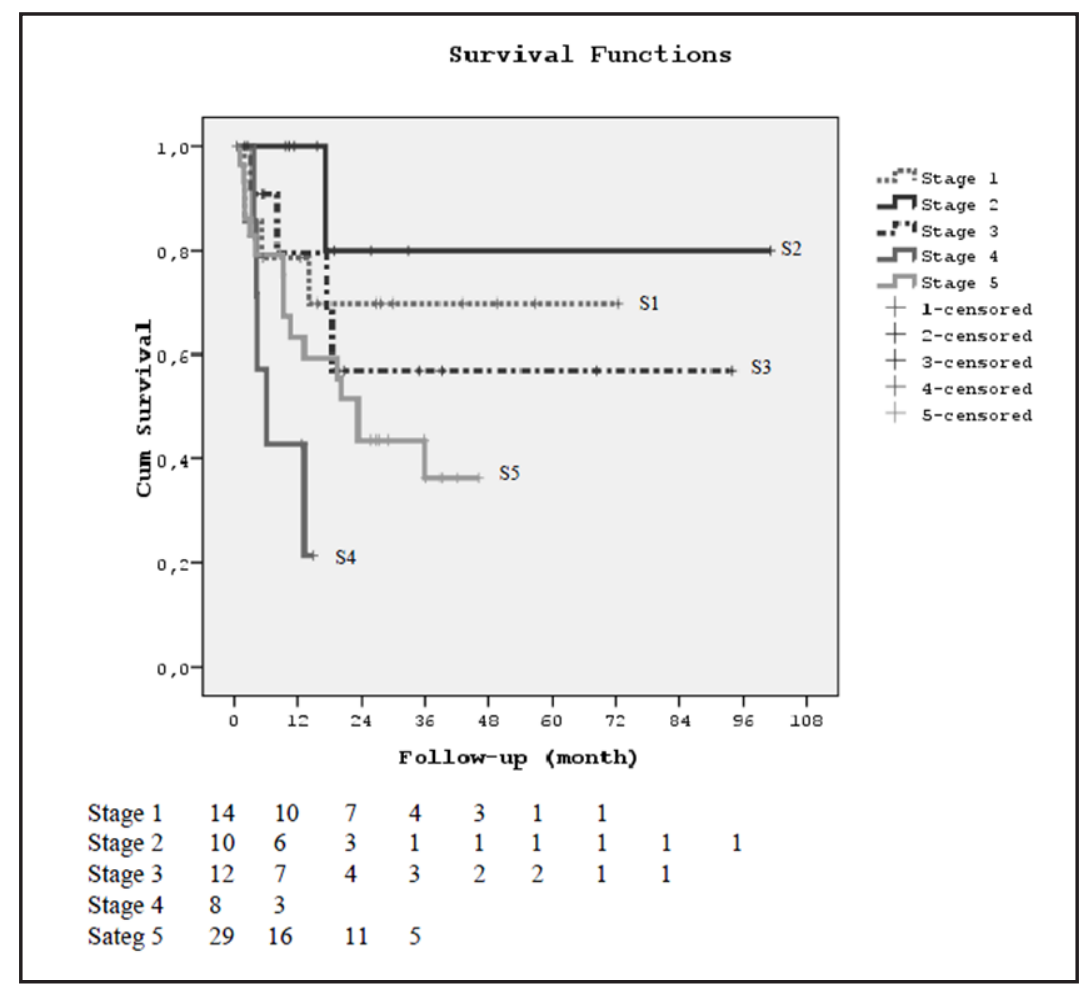

Fig. 2. Patient survival according to serum albumin level.
Survival Functions

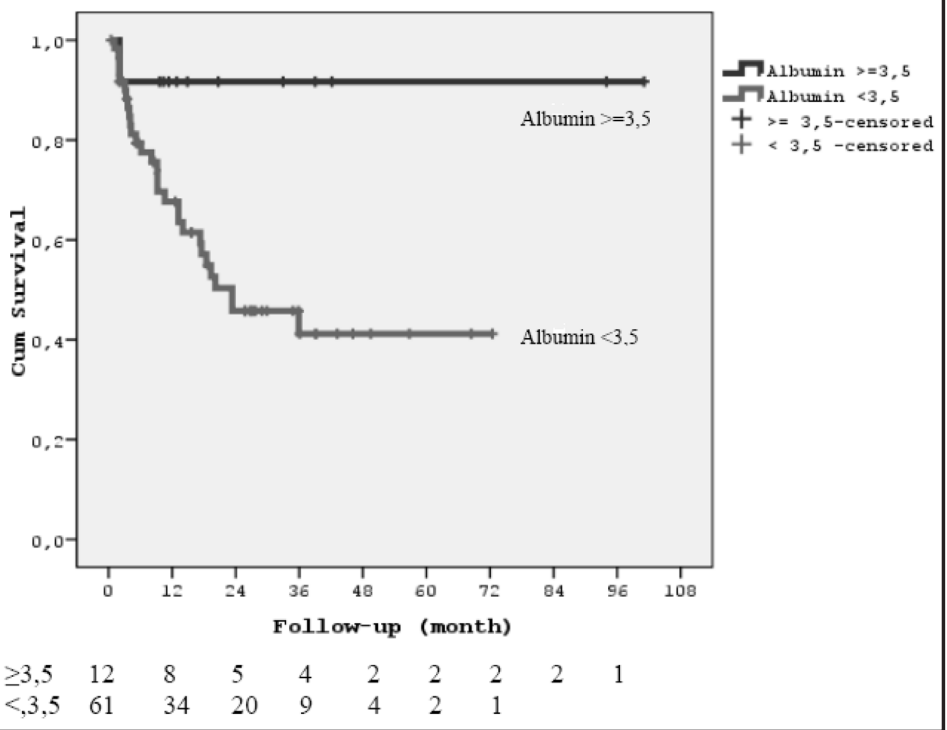

and $56.1 \pm 7.9 \%$, respectively. Corresponding figures were $84.4 \pm 7.2 \%$ and $73.9 \pm 9.4 \%$ in patients who did not need dialysis support (table 5).

Survival on dialysis was similar in males (mean $23.61 \pm 2.73$ months) as compared to females (mean 27.41 \pm 8.65 months) ( $p=0.519$ ). The survival of dialysis patients was better when age was less than 45 years. Survival on dialysis did not differ significantly with regard to underlying etiology of AA amyloidosis. 


\section{Kidney Blood Pressure Research}

\section{Cause of death}

At the end of follow-up period, 30 patients (41.1\%) died. In 12 of these patients, amyloidosis caused chronic nutritional debility, which led to cachexia, malnutrition, infection and death. Seven of the 30 deaths were related to the complications of renal disease i.e. hyperkalemia, hypervolemia. The cause was unknown in 11 patients.

\section{Discussion}

AA amyloidosis is a relatively rare disease, which may complicate chronic inflammatory diseases, chronic infections and FMF [2]. FMF appears to be the leading cause of AA amyloidosis in Turkey, followed by tuberculosis [6]; a similar etiologic pattern was observed in the present study as well.

The definite diagnosis of amyloidosis can be made by biopsy and microscopic demonstration of the typical amyloid deposits. Although kidney biopsy is positive in $100 \%$ of symptomatic cases, it necessitates hospitalization and carries a risk of bleeding; hence, less invasive biopsy sites have been suggested [7]. Duodenal biopsy is sensitive for diagnosing amyloidosis in chronic kidney disease patients, and highly correlates with renal amyloidosis [8]. Likewise, in the present study, we performed gastrointestinal tract (GIT) biopsies in patients with chronic kidney disease when renal biopsy was contraindicated.

The time of diagnosis was very late in our study; (serum creatinine $>4 \mathrm{mg} \%$ ) as far as renal disease is concerned. To our opinion there are 2 main reasons for this late referral:

1. Primary care physicians are not educated well enough for early referral to the nephrologists.

2. Health care system is not well organized in our country, which may result in unacceptable delays, even if the patients were referred by the primary care physicians in an early phase of the disease. This issue has been inserted into the discussion.

The natural history of AA amyloidosis is typically progressive, leading to multiple organ failure and death [4]. The prognosis of the patients with AA amyloidosis is difficult to determine from published series. It depends crucially on whether the report comes from a renal or a rheumatological unit [2]. Reports from renal units give a median survival of 24-31 months [9-11] while patients described from rheumatological units appear to have a better prognosis, with 5-year survival rates varying between $27 \%$ in untreated, and $93 \%$ in treated patients [12-15]. The most likely reason for this discrepancy is unfavourable effects of renal dysfunction on the ultimate outcome. Renal function is not always provided in reports from rheumatological units; in the studies that commented on renal function the GFR was generally about $50-60 \mathrm{ml} / \mathrm{min}$ compared to $20-30 \mathrm{ml} / \mathrm{min}$ in renal series [2]. The median calculated creatinine clearance was $27.00 \pm 52.49 \mathrm{ml} / \mathrm{min}$ in the present study and the median survival was 35.9 months which is better than reported results from other renal units.

Despite the fact that AA amyloidosis is a well-recognized complication of inflammatory diseases, there are very few studies evaluating prognostic markers, natural history and treatment of this disorder $[2,16]$.

Renal failure and a low serum albumin at diagnosis have been suggested as the most important predictors for a poor outcome [11,17]. Gertz et al. [11] analyzed 64 patients with AA amyloidosis and demonstrated that renal dysfunction (serum creatinine value of $>2 \mathrm{mg}$ / dl) at presentation is strongly associated with shorter survival. Other studies confirmed that serum creatinine concentration is an important predictive factor for the survival of AA amyloidosis patients, as well $[16,18]$. In the present study, a finding deserves special mention: although low serum albumin was the strongest predictor of death, proteinuria did not show this significance. We suggest that this may be a sign that malnutrition and GI involvement may ultimately be at least as important as renal disease in patients with AA amyloidosis. On the other hand, we cannot provide specific data to prove this hypothesis; 


\section{Kidney Blood Pressure Research}

mainly because, except one, all of the cases, who were performed GI endoscopy and biopsy suffered from GI amyloidosis as well in addition to renal amyloidosis.

The relationship between nephrotic syndrome and prognosis has been discussed in the literature. These studies have indicated that patients with nephrotic syndrome suffer from a worse prognosis [19]. Recently, it has been suggested that patients with chronic arthritis and proteinuria at baseline may predict mortality [20]. This suggestion is in line with some other studies, which show that reduced serum albumin is associated with a poor prognosis [21].

Joss et al. [2] have suggested that patients commenced renal replacement therapy or died within 3 months were significantly older, suffered from more advanced renal disease, more severe albuminuria and a lower serum albumin level. Also, they were more likely to be male and have a non-rheumatological etiology.

Another study has identified C-reactive protein (or serum amyloid A protein) during follow-up as prognostic markers [22].

In the present study, the patients who died were significantly older, more frequently suffered from tuberculosis, but less frequently suffered from FMF, and had more advanced renal disease and lower serum albumin. Serum albumin was a predictor of mortality in logistic regression analysis.

Either HD or PD can be used for treatment of ESRD due to amyloidosis. Moroni et al. [23] did not find any difference in survival at any time during dialysis between patients on HD or PD. However, HD had been suggested as the preferred dialysis modality [24] because PD can worsen hypoalbuminemia because of loss of amino acids to the peritoneal dialysate [25]. In the present study, most of the patients received HD treatment.

Survival of patients on dialysis treatment varies world-wide: a large American study found a median survival on dialysis of 20 months [26]. In the results of an Italian study, median survival was 25 months [23]. A Spanish study reported more encouraging results with a median survival of 52 months [27]. In the present study, median survival in dialysis patients was found to be 20.13 months.

In the literature, survival on dialysis has been particularly poor in males [2], but the effect of age is not clear. In a study, age did not affect survival on dialysis [2] while in another study, the survival was better among patients less than 45 years of age [25]. In the present study, gender difference did not affect survival on dialysis; however, the survival of dialysis patients was better among patients less than 45 years of age.

The underlying etiology of amyloidosis may have an effect on the ultimate outcome during dialysis, as well. Survival on dialysis has been suggested to be better in patients with AA amyloidosis complicating a rheumatological disorder. Median survival of the patients with a chronic rheumatological diagnosis was found to be of 32.2 months as compared to those with a non-rheumatological cause in whom survival was 3.2 months $(p=0.007)$ [2]. The patients with tuberculosis as their underlying cause of AA amyloidosis fared particularly poorly [2]. In the present study, survival on dialysis was similar in patients with FMF or tuberculosis compared to others as their underlying cause of AA amyloidosis. Although tuberculosis was a bad prognostic indicator in the predialysis period, this effect disappeared in patients receiving dialysis. We can only speculate on this finding by hypothesizing that, many confounding factors that can have an effect on the ultimate prognosis may blunt the effect of the primary etiology. Successful therapy of the underlying disease may be beneficial for the course of renal disease. However, in the present series, it is not possible to prove this hypothesis mainly for 2 reasons:

1. Majority of the patients were admitted to our institution with already advanced renal failure.

2. Since many different therapeutic schedules had been used in these patients and drug information was unavaliable, it was impossible to analyse the effects of treatment of the primary disease on the course of amyloidosis. 


\section{Kidney \\ Blood Pressure Research}

Generally renal failure and infection are the most common causes of death in patients with amyloidosis [13]. In a Dutch study, 35\% of the patients died from renal failure; the other causes included infection, gastrointestinal bleeding, bowel perforation and myocardial infarction [28]. In the Bristol study, infection accounted for $24 \%$ of deaths [10], compared to $8.5 \%$ of infectious mortality in the report from the Mayo clinic [11]. Our data shows that main causes of death in these patients were related to progression of amyloidosis (cachexia, malnutrition, infection) and complications of renal disease (hyperkalemia and hypervolemia).

\section{Conclusion}

The ultimate outcome of the patients with AA amyloidosis is poor. The vast majority of the patients admit to nephrology clinics with already established ESRD. Early referral may be helpful to improve prognosis.

\section{Conflict of Interests}

All authors state that they have nothing to disclose.

\section{References}

-1 Potysová Z, Merta M, Tesar V, Jancová E, Honsová E, Rysavá R: Renal AA amyloidosis: survey of epidemiologic and laboratory data from one nephrology centre. Int Urol Nephrol 2009;41:941-945.

2 Joss N, McLaughlin K, Simpson K, Boulton-Jones JM: Presentation, survival and prognostic markers in AA amyloidosis. QJM 2000;93:535-542.

-3 Dember L: Amyloidosis associated Kidney Disease. J Am Soc Nephrol 2006;17:3458-3471.

4 Gertz MA, Kyle RA: Amyloidosis: prognosis and treatment. Semin Arthritis Rheum 1994;24:124-138.

5 Obici L, Perfetti V, Palladini G, Moratti R, Merlini G: Clinical aspects of systemic amyloid diseases. Biochim Biophys Acta 2005;1753:11-22.

-6 Tuglular S, Yalcinkaya F, Paydas S, Oner A, Utas C, Bozfakioglu S, Ataman R, Akpolat T, Ok E, Sen S, Düsünsel R, Evrenkaya R, Akoglu E: A retrospective analysis for aetiology and clinical findings of 287 secondary amyloidosis cases in Turkey. Nephrol Dial Transplant 2002;17:2003-2005.

7 Tiitinen S, Myllykangas R, Helin H, Kaarela K: Modern trends in the diagnosis of secondary amyloidosis. Scand J Rheumatol Suppl 1987;67:30-31.

-8 Yilmaz M, Unsal A, Sokmen M, Harmankaya O, Alkim C, Kabukcuoglu F, Ozagari A: Duodenal biopsy for diagnosis of renal involvement in amyloidosis. Clin Nephrol 2012;77:114-118.

-9 Triger DR, Joekes AM: Renal amyloidosis--a fourteen-year follow-up. Q J Med 1973;42:15-40.

10 Browning MJ, Banks RA, Tribe CR, Hollingworth P, Kingswood C, Mackenzie JC, Bacon PA: Ten years' experience of an amyloid clinic--a clinicopathological survey. Q J Med 1985;54:213-227.

11 Gertz MA, Kyle RA: Secondary systemic amyloidosis: response and survival in 64 patients. Medicine 1991;70:246-256

-12 Schnitzer TJ, Ansell BM: Amyloidosis in juvenile chronic polyarthritis. Arthritis Rheum 1977;20:245-252.

-13 David J, Vouyiouka 0, Ansell BM, Hall A, Woo P: Amyloidosis in juvenile chronic arthritis: a morbidity and mortality study. Clin Exp Rheumatol 1993;11:85-90.

14 Berglund $\mathrm{K}$, Keller C, Thysell H: Alkylating cytostatic treatment in renal amyloidosis secondary to rheumatic disease. Ann Rheum Dis 1987;46:757-762.

15 Ahlmen M, Ahlmen J, Svalander C, Bucht H: Cytotoxic drug treatment of reactive amyloidosis in rheumatoid arthritis with special reference to renal insufficiency. Clin Rheumatol 1987;6:27-38. 


\section{Kidney \\ Blood Pressure Research}

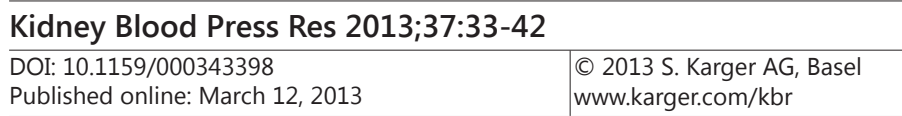

www.karger.com/kbr

Yilmaz/Unsal/Sokmen et al.: Renal Involvement in AA Amyloidosis

16 Tanaka F, Migita K, Honda S, Fukuda T, Mine M, Nakamura T, Yamasaki S, Ida H, Kawakami A, Origuchi T, Eguchi K: Clinical outcome and survival of secondary (AA) amyloidosis. Clin Exp Rheumatol 2003;21:343346.

17 Bergesio F, Ciciani AM, Manganaro M, Palladini G, Santostefano M, Brugnano R, Di Palma AM, Gallo M, Rosati A, Tosi PL, Salvadori M, Immunopathology Group of the Italian Society of Nephrology: Renal involvement in systemic amyloidosis: an Italian collaborative study on survival and renal outcome. Nephrol Dial Transplant 2008;23:941-951.

18 Sasatomi Y, Kiyoshi Y, Uesugi N, Hisano S, Takebayashi S: Prognosis of renal amyloidosis: a clinicopathological study using cluster analysis. Nephron 2001;87:42-49.

19 Bohle A, Wehrmann M, Eissele R, von Gise H, Mackensen-Haen S, Müller C: The long-term prognosis of AA and AL renal amyloidosis and the pathogenesis of chronic renal failure in renal amyloidosis. Pathol Res Pract 1993;189:316-331.

20 Fernández-Nebro A, Olivé A, Castro MC, Varela AH, Riera E, Irigoyen MV, García de Yébenes MJ, GarcíaVicuña R: Long-term TNF-alpha blockade in patients with amyloid A amyloidosis complicating rheumatic diseases. Am J Med 2010;123:454-461.

21 Lachmann HJ, Goodman HJ, Gilbertson JA, Gallimore JR, Sabin CA, Gillmore JD, Hawkins PN: Natural history and outcome in systemic AA amyloidosis: N Engl J Med 2007;356:2361-2371.

-22 Falck HM, Maury CP, Teppo AM, Wegelius O: Correlation of persistently high serum amyloid A protein and C-reactive protein concentrations with rapid progression of secondary amyloidosis. Br Med J (Clin Res Ed) 1983;286:1391-1393.

23 Moroni G, Banfi G, Montoli A, Bucci A, Bertani T, Ravelli M, Pozzi C, Leonelli M, Lupo A, Volpi A, et al: Chronic dialysis in patients with systemic amyloidosis: the experience in northern Italy. Clin Nephrol 1992;38:8185.

-24 Fassbinder W, Brunner FP, Brynger H, Ehrich JH, Geerlings W, Raine AE, Rizzoni G, Selwood NH, Tufveson G, Wing AJ: Combined report on regular dialysis and transplantation in Europe, XX, 1989. Nephrol Dial Transplant 1991;6:5-35.

25 Ylinen K, Grönhagen-Riska C, Honkanen E, Ekstrand A, Metsärinne K, Kuhlbäck B: Outcome of patients with secondary amyloidosis in dialysis treatment. Nephrol Dial Transplant 1992;7:908-912.

-26 Port FK, Nissenson AR: Outcome of end-stage renal disease in patients with rare causes of renal failure. II. Renal or systemic neoplasms. Q J Med 1989;73:1161-1165.

27 Martinez-Vea A, García C, Carreras M, Revert L, Oliver JA: End-stage renal disease in systemic amyloidosis: clinical course and outcome on dialysis. Am J Nephrol 1990;10:283-289.

28 Janssen S, Van Rijswijk MH, Meijer S, Ruinen L, Van der Hem GK: Systemic amyloidosis: a clinical survey of 144 cases. Neth J Med 1986;29:376-385. 